\title{
KUITURA \\ I SPOIFCZEN'STW0

\section{ANTROPOLOGOWIE I ANTROPOLOŻKI NA WOJENNEJ ŚCIEŻCE ORAZ ICH DYLEMATY MORALNE Z TYM ZWIĄZANE}

Książka Michała W. Kowalskiego Antropolodzy na wojnie. O „brudnej” użyteczności nauk społecznych jest dziełem ważnym i inspirującym*. Opowiada historię antropologii i jej dzień dzisiejszy z unikalnej perspektywy, ukazując problemy zazwyczaj przemilczane i rozważając kwestie rzadko pojawiające się w głównym nurcie tej dyscypliny. Sam autor stwierdza we wstępie, że podejmuje „problem wykorzystania w działaniach wojennych wiedzy antropologów o kulturze «innych społeczeństw»”, a także opisuje - co ważne - „jak zaangażowanie badaczy społecznych w pracę na rzecz wojska i wywiadu wpływało na samą antropologię” (s. 14). Przez rozważanie „brudnego” użytku czynionego przez antropologów ze swej wiedzy, czyli wykorzystywania jej w interesie własnego państwa, Kowalski dekonstruuje autostereotyp przedstawicieli tej dyscypliny jako empatycznych badaczy terenowych i rzeczników badanych społeczności działających dla ich dobra. W pewnym sensie „prze-pisuje” historię dyscypliny, rozważając ją w kontekście wojny i działalności wywiadowczej badaczy. Relacjonuje też towarzyszącą temu refleksję i ukazuje, jak zmieniały się formułowane przez instytucje antropologiczne standardy etyczne i wrażliwość samych etnografów.

Książka jest podzielona na kilka dobrze wyróżnionych rozdziałów odpowiadających historycznemu rozwojowi omawianej problematyki. W pierwszym, pt. „Antropolodzy w koloniach — wojny «białego człowieka»”, autor zajmuje

\footnotetext{
Adres do korespondencji: grazyna.kubica-heller@uj.edu.pl

* Michał W. Kowalski, Antropolodzy na wojnie. O „brudnej” użyteczności nauk społecznych, Wydawnictwa Uniwersytetu Warszawskiego, Warszawa 2015, stron 674.
} 
się związkami między antropologią a kolonializmem, a szczególnie konfliktami wywoływanymi przez ekspedycje wojskowe, które były także badawczymi. Omawia kilka takich przypadków w Azji Południowej, na Bliskim Wschodzie, w Afryce, na wyspach Pacyfiku, w Ameryce Południowej i Północnej, kiedy to wykorzystywano wiedzę o kulturze tamtejszych ludów do ich pacyfikacji. Relacjonuje działania konkretnych badaczy brytyjskich, niemieckich i amerykańskich, a także dyskusje, które towarzyszyły ich zaangażowaniu wojennemu.

Jeśli chodzi o Brytyjczyków, to jest tu mowa o kapitanie Jamesie Cooku, o którym autor pisze, że „uznany jest za pierwszego antropologa w mundurze" (s. 52, jednak w artykule, do którego jest odnośnik, nie znalazłam takiego określenia); o podróżnikach działających w Azji Środkowej: Arthurze Conollym i Alexandrze Burnesie, a także oficerach: Charlesie Callwellu i Francisie Edwardzie Younghusbandzie; archeologach-szpiegach: Thomasie E. Lawrensie (Lawrence $z$ Arabii) oraz Gertrudzie Bell (obie postaci stały się bohaterami filmów fabularnych). Wspomiany jest Robert $S$. Rattray, który według autora nie był „antropologiem w ścisłym znaczeniu tego słowa, ale stał się nim na mocy decyzji administracyjnych" (s. 86), co nie jest zgodne z prawdą, gdyż Rattray studiował w Oksfordzie u Roberta Maretta i w 1914 roku uzyskał Diploma in Anthropology, był zatem pełnoprawnym antropologiem ${ }^{1}$. Autor pisze o holenderskim orientaliście i językoznawcy (oraz szpiegu) Christiaanie Snoucku Hurgronje i Finie Carlu Gustafie Mannerheimie, oficerze rosyjskiej armii eksplorującym (operacyjnie) środkową Azję.

W książce jest też mowa o niemieckiej antropologii kolonialnej, rozumieniu kultury jako narzędziu budowania tożsamości narodowej, a także rozwoju antropometrii (powstanie afrykańskich Hererów w 1904 roku zostało wywołane - jak pisze autor - działaniami żołnierzy, którzy przekopywali cmentarze $\mathrm{w}$ poszukiwaniu czaszek na zamówienie badaczy rasy z Niemiec). Zrelacjonowane są także niemieckie próby wzniecenia ogólnoislamskiego powstania i działania szpiega-naukowca Oskara Rittera von Niedermayera na Bliskim Wschodzie, ekspedycje wybitnego antropologa Leo Frobeniusa (m.in. miał zorganizować „centrum propagandowe turecko-niemieckiej świętej wojny", s. 122) oraz agenta wywiadu habsburskiego i archeologa Aloisa Musila, a także badania prowadzone $\mathrm{w}$ czasie pierwszej wojny światowej w niemieckich obozach jenieckich i w czasie ekspedycji na tereny przyfrontowe.

Część poświęcona wczesnej antropologii amerykańskiej podkreśla jej znaczenie dla tworzenia państwowości, a zwłaszcza „wojny o pogranicze”, i działalność Johna Wesleya Powella, geologa i żołnierza, założyciela Bureau of Ethnology. Jest także mowa o Jamesie Mooneyu, który na zlecenie Departamentu Wojny badał rozprzestrzeniający się wśród Indian Taniec Duchów, przez władze uważany za niebezpieczny ruch, a później stał się ich rzecznikiem. Wiele uwagi

${ }^{1}$ Zob. Peter Rivière, The Formative Years: The Committee for Anthropology 1905-1938, w: A History of Oxford Anthropology, Peter Rivière (red.), Berghahn Books, Oxford 2007, s. 43-61. 
zostało poświęcone Franzowi Boasowi, a szczególnie jego wystąpieniu przeciw działalności szpiegowskiej czterech archeologów (czyli reprezentantów dyscypliny wchodzącej w skład „czteropolowej” antropologii w tradycji amerykańskiej), prowadzonej pod przykrywką badań naukowych w Ameryce Środkowej. Na łamach pisma „The Nation” w 1919 roku Boas oskarżył ich (bez podawania nazwisk) o „prostytuowanie nauki” i podkreślił, że naczelną zasadą życia naukowców jest służba prawdzie. Wtedy ze strony środowiska (głównie American Anthropological Association) spotkały go szykany, a dopiero później doceniono znaczenie jego gestu. Autor omawia dyskusję wokół tej sprawy i wraca do niej w dalszych częściach książki, traktując stanowisko Boasa jako wzorzec postawy etycznej antropologa. Rozdział ten kończy się ogólnym omówieniem amerykańskich nauk społecznych na przełomie lat trzydziestych i czterdziestych XX wieku.

Kolejny rozdział „Antropolodzy na frontach II wojny światowej” zawiera omówienie wojennego zaangażowania antropologów niemieckich, japońskich, brytyjskich i amerykańskich. Autor zaczyna od tych pierwszych i podkreśla, że „u podłoża wojny wznieconej przez Hitlera znajdowały się koncepcje wywiedzione $z$ teorii antropologicznych" w sposób wybiórczy i często sprzeczny z intencjami twórców (s. 159). Omawia „wojnę o czystość rasową” oraz rolę Eugena Fischera i Instytutu Antropologii w tym przedsięwzięciu. Przytacza opinię innych badaczy o tym, że „czynnikiem, który niejako skanalizował istotność problematyki rasowej w Niemczech była utrata posiadłości kolonialnych" i powrót do Niemiec weteranów wojen kolonialnych (s. 170) oraz że idee „ubóstwa umysłowego ludzkości” i „przestrzeni życiowej” Hitler zaczerpnął od Friedricha Ratzela, który używał ich w zupełnie innym kontekście i znaczeniu. Wymienia zdeklarowanych zwolenników nazizmu wśród antropologów: Wilhelma Schmidta, Ottona Reche i Eugena Fischera (który dokonywał „ewaluacji rasowych"), a także wskazuje drugi typ zaangażowania w funkcjonowanie nazistowskiego aparatu eksterminacji na przykładzie Richarda Thurnwalda, który był recenzentem w przewodzie doktorskim Evy Justin. Dowodziła ona, że u Cyganów czynniki rasowe są tak silne, iż nie równoważą wpływów społecznych i środowiskowych. Badała dzieci cygańskie przeznaczone do deportacji (po zakończeniu projektu wszystkie trafiły do KL Auschwitz i zostały uśmiercone). Autor przedstawia niemiecką politykę wschodnią i pracę Institut für Deutsche Ostarbeit ${ }^{2}$, a także innych tego typu instytucji. Wspomniana jest książka znanego antropologa Wilhelma Mühlmanna, Krieg und Frieden, w której autor do-

\footnotetext{
${ }^{2}$ Niedawno ukazały się dwa tomy na temat działalności tej instytucji opracowane przez krakowskich etnologów: Elżbieta Duszeńko-Król, Kolekcja fotograficzna Institut für Deutsche Ostarbeit Krakau 1940-1945. Zdjęcia z Polski, Wydawnictwo Uniwersytetu Jagiellońskiego, Kraków 2014; Antropologia $i$ etnologia w czasie wojny. Działalność Sektion Rassen- und Volkstumsforschung Institut fur Deutsche Ostarbeit, Krakau 1940-1944, w świetle nowych materiałów źródłowych, Małgorzata Maj (red.), Wydawnictwo Uniwersytetu Jagiellońskiego, Kraków 2015.
} 
wodził kulturotwórczej roli wojny. Omawiane są także inne kwestie: poszukiwania źródeł germańskości przez stowarzyszenie Ahnenerbe; powrót na Bliski Wschód i rozbudzanie arabskiego nacjonalizmu wzorowanego na niemieckim narodowym socjalizmie; poszukiwania aryjskości w Tybecie. Autor relacjonuje również rozliczenia $z$ antropologią nazistowską i dyskusję na temat odpowiedzialności jej przedstawicieli (co ma miejsce dopiero od niedawna).

Kolejnym tematem jest antropologia japońska, która na skutek ekspansji kolonialnej Japonii uzyskała nowe tereny badawcze. Nie rozliczyła się ona ze swojej działaności w czasie wojny, a jej przedstawiciele spokojnie kontynuowali później karierę naukową.

Antropologowie brytyjscy rozwijali swoje zainteresowania z okresu międzywojennego, a ich udział w wysiłku wojennym kraju nie był zinstytucjonalizowany. Autor wskazuje, że niewiele wiadomo o zaangażowaniu poszczególnych badaczy w działania wojenne. Najważniejsi z nich: Edward Evans-Pritchard (powołany do wojska, miał organizować bunt wśród ludu Anuak, rozpoznać ruch alawitów i mieszkańców północnoafrykańskiej Cyrenajki) i Edmund Leach (tworzył siatkę szpiegowsko-partyzancką wśród Kaczinów), niechętnie wypowiadali się na ten temat. Bardziej skory do opowiadania o swojej wojennej działalności był Tom Harrison ${ }^{3}$ (organizował partyzantkę Dajaków na Borneo), ale warto było także wspomnieć o tym, że był jednym z inicjatorów projektu Mass Observation. Była to brytyjska społeczna organizacja badawcza założona w 1937 roku przez Harrissona, poetę Charlesa Madge'a i filmowca Humphreya Jenningsa. Jej celem było dokumentowanie codziennego życia Brytyjczyków przez około pięciuset ochotniczych obserwatorów ${ }^{4}$.

Więcej wiadomo o działalności antropologów australijskich: Adolphus Elkin opublikował broszurę dyskredytującą poglądy rasistowskie nazistów, a Ernest Chinnery, Francis Williams, William Groves i inni znaleźli zatrudnienie $\mathrm{w}$ różnych agendach rządowo-wojskowych i przygotowywali materiały i szkolenia dla żołnierzy, tworzyli raporty, ich skutkiem było między innymi zwrócenie uwagi na sytuację ludności rdzennej podczas wojny.

Najwięcej miejsca Kowalski poświęca antropologii amerykańskiej, która wtedy - jak pisze — otworzyła się na świat. Badacze aktywnie przyczyniali się do wysiłku wojennego swojego kraju: powstawały instytucje zajmujące się wojennymi badaniami antropologicznymi w kraju i na okupowanych terytoriach. Główną animatorką tych działań była Margaret Mead. Z American Anthropological Association (AAA) wyłoniło się Society for Applied Anthropology, a całe środowisko poparło ideę wsparcia działań rządu wiedzą antropologiczną. Conrad Arensberg służył w wywiadzie armii Stanów Zjednoczonych i zajmował się

\footnotetext{
${ }^{3}$ Do podanego przez autora spisu filmów i książek na jego temat dorzuciłabym jeszcze świetny dokument BBC z 2007 roku Tom Harrisson: The Barefoot Anthropologist.

${ }_{4}^{4}$ Zob. Bronisław Malinowski, Ogólnonarodowa służba wywiadowcza, tłum. Janusz Mucha, w: Dzieła, t. 10, Wydawnictwo Naukowe PWN, Warszawa 2001.
} 
internowanymi obywatelami pochodzenia japońskiego. Prowadzono szkolenia i opracowywano podręczniki dla żołnierzy (Ralph Linton, Felix Keesing, Kenneth Emory), w których między innymi walczono $z$ uprzedzeniami rasowymi. Powstały instytucje amerykańskiej antropologii wojennej: Biuro Koordynatora Informacji i Biuro Informacji Wojennej. Nieformalnym doradcą prezydenta Franklina Roosevelta był Aleš Hrdlička, słynny antropolog fizyczny czeskiego pochodzenia. W otoczeniu prezydenta znaleźli się także inni antropologowie. Jack Harris i Carleton Coon wykonywali tajne operacje w Afryce.

Obszernie autor omawia projekt „The Study of Culture at a Distance”, kierowany przez Margaret Mead i Ruth Benedict, którego pokłosiem była słynna książka autorstwa Benedict Chryzantema i miecz. Autor podaje bardzo ciekawy przykład różnic między opiniami badaczy na temat tego, jak należy postępować z pokonanymi Japończykami. Morris Opler i Ruth Benedict optowali za tym, by nie stosować polityki represji, która przynosi odwrotne skutki, lecz „podbój bez dyshonoru” i utrzymanie pozycji cesarza. Natomiast Earnest Hooton, antropolog fizyczny (dodam, że przed pierwszą wojną światową studiował u Roberta Maretta w Oksfordzie) zajmujący się badaniami rasowymi, opracował plan wyeliminowania japońskiej agresywności między innymi przez „wygnanie, uwięzienie i sterylizację wszystkich członków japońskiej rodziny królewskiej”, by wyeliminować kult cesarza. Ten przykład dobrze ilustruje, jak różne wnioski mogli formułować antropologowie w zależności od przyjętych założeń teoretycznych.

W rozdziale znajdujemy również relacje dotyczące Johna Embree (prowadził badania terenowe w Japonii przed wojną) i jego krytyki ówczesnych badań; Cory Du Bois i jej pracy dla wywiadu na terenie Cejlonu; Gregory'ego Batesona i jego działalności tego typu w Birmie, a także jego wątpliwości i problemów etycznych, które się z tym wiązały. Poznajemy jego analizę interesująca dla przyszłych władz kolonialnych. Jedną z przyczyn załamywania się systemu brytyjskiego w Indiach było — zdaniem Batesona — to, że kolonizatorzy traktowali miejscową ludność jak dzieci w brytyjskim modelu rodziny. Brytyjczycy oczekiwali, że Hindusi odtworzą model społeczeństwa brytyjskiego, tak jak ich potomstwo miało w przyszłości odtworzyć idealny obraz swoich rodziców. Bateson postulował, by wzorować się raczej na modelu rodziny amerykańskiej, w której rodzice pochodzą z różnych kultur, a wychowanie polega na obserwowaniu dzieci i siebie nawzajem, co przynosi dzieciom największe korzyści. Formułował też inne trafne rekomendacje. Po wojnie raczej negatywnie oceniał dokonania antropologii stosowanej.

W podsumowaniu konsekwencji wojny Kowalski stwierdza, że dla amerykańskiej antropologii okres ten był przełomowy.

W kolejnej części, „Antropolodzy i "zimna wojna»", autor analizuje kilka zagadnień związanych $z$ udziałem antropologów w konfliktach zbrojnych po zakończeniu drugiej wojny światowej i zauważa pokrywanie się etapów historii politycznej z kolejnymi okresami w rozwoju antropologii: „gorące lata zimnej 
wojny” to czas dominacji funcjonalizmu (do lat sześćdziesiątych), okres „odprężenia” to czas „rozmycia paradygmatów” i „kryzysu reprezentacji” (s. 44). Cezurą jest wojna wietnamska. Szkoda, że problem ten i znaczenie takiej periodyzacji nie zostały głębiej zanalizowane. Należało się odwołać do kontekstu politycznego i atmosfery intelektualnej tamtych czasów, a szczególnie do teorii postkolonialnej.

Znajdujemy tu omówienie powojennych programów badawczych, głównie kontynuacji „The Study of Culture at a Distance” — projektu, który miał cel polityczny: chodziło o możliwość przewidywania zachowania sojuszników i wrogów. Brali w nim udział, obok Mead i Benedict, także Geoffrey Gorer, Rhoda Métraux i Ruth Bunzel (autor nie wymienia Suli Benet i jej asystentki Alicji Iwańskiej, która w swoich wspomnieniach opisuje pracę $\mathrm{w}$ tym projekcie ${ }^{5}$ ). W latach 1999-2005 wydano ponownie w opracowaniu krytycznym publikacje będące wynikiem tych prac (w sześciu tomach) ${ }^{6}$. Szkoda, że autor nie odwołał się do nich.

$\mathrm{Na}$ początku lat pięćdziesiątych wywiad amerykański (przy współpracy antropologów) zaczął szkolić tybetańskich powstańców. Później w kilku krajach Dalekiego Wschodu i Ameryki Łacińskiej działał Charles Bohannan, ekspert od walki partyzanckiej i jednocześnie antropolog, który postulował, by wykorzystywać wiedzę o kulturze i wpływać na sposób myślenia przeciwników. Podczas wojny wietnamskiej relizowany był program Civil Operations and Revolutionary Development oraz Phoenix, będący inicjatywą CIA, a według późniejszych krytyków polegający na „mordowaniu i torturach” (s. 372).

Autor szczegółowo omawia projekt Camelot, który zresztą nie doszedł do skutku. Jego celem było „określenie możliwości stworzenia ogólnego modelu systemów społecznych, który umożliwi przewidywanie i wpływ politycznie istotnych aspektów zmiany społecznej w rozwijających się krajach świata" (s. 379), chodziło o oszacowanie zagrożenia wojną domową. Jeden z uczestników projektu, Chilijczyk z pochodzenia, pochwalił się tym przed badaczami w swoim rodzinnym kraju. Tam odebrano te plany jako przejaw amerykańskiego imperializmu i wybuchł międzynarodowy skandal. Władze amerykańskie zrezygnowały z ich realizacji. Późniejsi interpretatorzy projektu Camelot zwracali uwagę na to, że współpraca $z$ rządem była dobrze opłacana, dawała poczucie realizowania ważnej misji, a także niezależność i swobodę prowadzenia badań, ale groziła zawodową marginalizacją. Zwracano też uwagę, że sam pomysł badania był raczej socjologiczny niż antropologiczny i opierał się na ukrytym założeniu, że wojsko pełni rolę stabilizującą, a działania partyzanckie przeciwnie.

${ }^{5}$ Alicja Iwańska, Potyczki i przymierza. Pamiętnik 1918-1985, Gebethner i Ska, Warszawa 1993, s. $348-351$.

${ }^{6}$ Margaret Mead, Researching Western Contemporary Cultures, William O. Beeman (red.), tomy 1-6, Berghan Books, New York 1999-2005. 
Relacjonowana jest także „kontrowersja tajlandzka”, czyli zaangażowanie badaczy na zlecenie Pentagonu w studium mniejszości etnicznych w Tajlandii, co miało pozwolić na przeciwdziałanie radykalizacji nastrojów. Zaangażowanie to zostało opisane (na podstawie materiałów jednego $z$ badaczy skopiowanych przez jego studenta) w „New York Review of Books” przez Erica Wolfa i Josepha Jorgensena, członków Komitetu Etyki AAA. Wtedy to, na początku lat siedemdziesiątych, ustała współpraca antropologów amerykańskich z instytucjami wojskowymi, co zapewne było spowodowane ogłoszeniem przez AAA zasad odpowiedzialności zawodowej i wycofaniem instytucjonalnego poparcia dla różnych programów realizowanych przez wojsko (mogły jednak istnieć inne formy współpracy).

W tym kontekście autor relacjonuje też badania ludu Yanomami prowadzone przez Napoleona Chagnona, który starał się ukazać jego „pierwotną agresję". Przedstawia także krytykę pracy tego badacza, która odbiła się szerokim echem w środowisku antropologów. Patrick Tierney i John Gledhill wykazali, że Chagnon wpływał na badaną społeczność (rozdawał toporki i maczety) i sprowokował wojnę. Nie uwzględniał kontekstu historycznego, traktował Yanomami instrumentalnie, badając ich jako grupę kontrolną $\mathrm{w}$ testowaniu dla Atomic Energy Commission wpływu promieniowania na mutacje genetyczne. Wszystkie te przypadki prowokowały gorące dyskusje i rosnące wyczulenie środowiska antropologów na kwestie etyczne badań terenowych.

Wreszcie ostatnia część „Współczesność - antropolodzy na «wojnie z terrorem»" rozpoczyna się od konstatacji, iż interwencje w Iraku i Afganistanie pokazały, jak ważna jest wiedza o kulturze przeciwnika i jak bardzo zawiodły tradycyjne metody prowadzenia wojny. Obszernie omawiany jest kontekst i założenia programu Human Terrain System (HTS). Został on uruchomiony przez Departament Obrony Stanów Zjednoczonych w roku 2005 i od początku był jawny. Następnie dogłębnie analizowany jest Army Field Manual 3-24 i Human Terrain Team Handbook. Autor prezentuje tu głównie własną interpretację. Przytacza także opinie zwolenników i krytyków HTS oraz dyskusje toczone na łamach czasopism wojskowych i antropologicznych.

Książkę wieńczy „Zakończenie. Militaryzacja — przeszłość i przyszłość antropologii?", w którym autor formułuje wnioski ze swych badań. Związki antropologii z wojskiem i wywiadem — jego zdaniem — były częste, motywowane rozszerzeniem imperium, obroną czystości rasy, demokracji, kraju, walką z terroryzmem. Ważne czynniki stanowiły także indywidualne korzyści, które badacze czerpali ze współpracy $z$ wojskiem oraz swoboda $w$ prowadzeniu badań Armia zwracała się o pomoc do badaczy, gdy zawodziły tradycyjne metody działań wojennych. Dopóki wojnę uznawano za sprawiedliwą, dopóty działalność na rzecz wojska była akceptowana społecznie jako służba dla kraju. Sytuacja zmieniła się na początku lat siedemdziesiątych wraz ze zmianą postawy wobec wojny wietnamskiej. W 1971 roku uchwalono Kodeks Etyki AAA, w którym 
uznaje się pracę dla wojska i wywiadu za sprzeczną z etyką badań antropologicznych. Po trzydziestu latach wskutek zamachów z 11 września 2001 r. i rozpoczęcia „wojny z terrorem” społeczne przyzwolenie na współpracę antropologów z armią wzrosło i zarząd AAA wsparł przygotowania do programu HTS. Analiza materiałów wykazała, iż głównym celem antropologii wojskowej stała się możliwość manipulowania kulturą „przeciwnika”, by osiągnąć konkretne cele. Wywołało to reakcję środowiska naukowego zaniepokojonego zagrożeniem, jakie militaryzacja antropologii ma dla samej dyscypliny i dla demokracji.

Co warte podkreślenia, książka oprócz obszernej bibliografii i listy źródeł internetowych zawiera także indeks osób i indeks pojęć oraz załączniki (dokumenty związane $z$ HTS).

Głównym mankamentem tej pracy jest to, że chociaż w dużym stopniu traktuje ona o historii antropologii, to autor nie bierze pod uwagę zmian, jakie dokonały się $\mathrm{w}$ dyscyplinie. Jest to bardzo dobry przykład podejścia do historii antropologii nazywanego przez George'a Stockinga prezentyzmem. Według niego polega ono na poszukiwaniu w przeszłości bezpośredniego odniesienia do teraźniejszości. Proces, w którym całość historycznej przeszłości produkuje całość jej przyszłych skutków, zostaje zredukowany do poszukiwania genezy obecnych zjawisk. Szuka się w przeszłości przykładów, które wydają się podobne do ważnych obecnie, a następnie kieruje się ku teraźniejszości, wyznaczając ich pochodzenie. Interpretacja jest raczej sądem niż rozumieniem, a poszczególne zjawisko historyczne zostaje wyrwane ze swego kontekstu i włożone w abstrakcyjny związek ze współczesnym analogonem. Takie podejście prowadzi do anachronicznych i błędnych interpretacji. Jako alternatywę Stocking proponuje "historycyzm”, który - jak zapewnia - rozumie bez epistemologicznego podtekstu, jako zaangażowanie $\mathrm{w}$ rozumienie przeszłości dla niej sa$\mathrm{mej}^{7}$.

Ów prezentystyczny impuls w zakończeniu książki opisuje sam autor: „Zainspirowany toczącą się obecnie dyskusją na temat realizacji programu HTS i wynikających $z$ tego przedsięwzięcia zmian roli antropologii i tradycyjnie rozumianych zadań stawianych przed antropologami, postanowiłem przeanalizować historyczne przykłady współpracy antropologów z wojskiem i agencjami wywiadowczymi, w których wiedza antropologów o kulturze «innych społeczeństw» była wykorzystywana w prowadzonych przeciwko tym społecznościom działaniach wojennych" (s. 588). Kowalski dostrzegł zatem problem i postarał się odszukać w przeszłości podobne sytuacje. Niestety efektem tego podejścia są grzechy prezentyzmu związane z niedostateczną kontekstualizacją (konkretne problemy referuję poniżej).

${ }^{7}$ George W. Stocking, Jr, On the Limits of „Presentism” and „Historicism” in the Historiography of the Behavioral Sciences, w: George W. Stocking, Jr, Race, Culture, and Evolution. Essays in the History of Anthropology, The University of Chicago Press, Chicago 1982 [1968], s. 1-12. 
Praca Michała Kowalskiego otwiera jednak bardzo ważną perspektywę, którą należy docenić i podkreślić. Zasady takiego spojrzenia sformułował inny historyk antropologii, David Mills, który proponuje zainteresowanie się tym, co ni e pasuje do modelu, otwarcie się na to, czego nie spodziewamy się usłyszeć, bycie gotowym na zmianę pytań, które zadajemy przeszłości ${ }^{8}$. Ja z kolei nazwałam swoje podejście „alternatywną historią dyscypliny” " 9 I właśnie książka Kowalskiego jest również taką alternatywną historią.

Podsumowując tę metodologiczną uwagę chciałabym podkreślić, że badania historyczne należy prowadzić tak, by odczytać i zrozumieć ówczesne koncepcje czy praktyki w ich własnym kontekście. Trzeba badać historię dla niej samej, jak postulował Stocking. Nam, antropologom, to jednak nie wystarcza: zrozumiawszy tamtą rzeczywistość, chcemy jej zadać współczesne pytania albo ocenić tamte praktyki i koncepcje pod względem współczesnych standardów, by odnaleźć nowatorskie rozwiązania czy wręcz przeciwnie - stwierdzić ich zgubny wpływ na rzeczywistość społeczną lub teorię antropologiczną. Książka Kowalskiego zawiera niedociągnięcia wynikające z perspektywy prezentystycznej, ale jednocześnie jest ważnym głosem opisującym historię antropologii i jej dzień dzisiejszy w sposób nowatorski.

Jednym z prezentystycznych uchybień jest coś, co można nazwać „anachronizmem terminologicznym”. Autor we wstępie pisze, że przyjmuje „szeroką definicję pojęcia «antropolog» $z$ uwagi na to, że w perspektywie historycznej zmieniał się sposób ujmowania przynależności do tej grupy zawodowej" (s. 19) i w dodatku różnie ją rozumiano w różnych tradycjach narodowych. I przyjmuje za Ruth Benedict, że „antropologami są wszyscy ci badacze społeczni, którzy biorą za przedmiot swoich studiów "społeczeństwa inne niż nasze»" (s. 20). Może jest to dobry punkt wyjścia, ale rozważając ważne sprawy odpowiedzialności dyscypliny za moralnie wątpliwe przedsięwzięcia w przeszłości i obecnie, należałoby bliżej określić, jak rozumiano wtedy, w danym miejscu, czym jest antropologia i jakie były jej instytucjonalne przejawy. Autor w pierwszej części książki pisze głównie o archeologach, antropologach fizycznych i podróżnikach, których trudno nazwać „badaczami społecznymi”. Pojawiają się też inne terminy, jak „etnologia” (s. 65), jednak nie zostaje podane ich znaczenie, a było ono wówczas zupełnie różne od współczesnego i odwoływało się do zróżnicowania rasowego ludzkości. Czasami autor pisze, jak rozumiano antropologię $\mathrm{w}$ różnych tradycjach, ale czyni to niekonsekwentnie i często anachronicznie. W książce brakuje szerszej kontekstualizacji, która pokazywałaby wymiar instytucjonalny antropologii, a także wymiar intelektualno-teoretyczny omawianych praktyk.

${ }^{8}$ David Mills, Difficult Folk? A Political History of Social Anthropology, Berghahn Books, Oxford 2008, s. 27.

${ }^{9}$ Grażyna Kubica, Maria Czaplicka, płeć, szamanizm, rasa. Biografia antropologiczna, Wydawnictwo Uniwersytetu Jagiellońskiego, Kraków 2015. 
Innym ważnym problem jest analityczność tej książki. Autor głównie omawia pracę analityczną innych autorów, czasami dodając swoje wnioski, ale bardzo rzadko sięga do źródeł, by przedstawić własne analizy. Czyni tak w przypadku materiałów związanych z HTS. Nie prowadził własnych poszukiwań archiwalnych, ani nie weryfikował tych, na które się powołuje. Warto jednak docenić, że sięga do narracji autobiograficznych i biografii, gdzie można znaleźć informacje, które nie pojawiają się w pracach naukowych ich bohaterów. Ogólnie rzecz biorąc, prezentowany materiał często robi wrażenie relacji z badań innych badaczy, a nie własnej konsekwentnej analizy, wskutek czego pojawiają się częste powtórzenia. Książka wiele zyskałaby na „dociśnięciu" analizy, formułowaniu wniosków po każdym rozdziale i podrozdziale. W efekcie monografia byłaby mniej obszerna, a treść - mniej chaotyczna.

Istnienie książki Hanny Schreiber z 2013 roku Świadomość międzykulturowa. Od militaryzacji antropologii do antropologizacji wojska ${ }^{10}$ jest odnotowane jedynie $\mathrm{w}$ przypisie (na s. 15). Schreiber jest specjalistką w dziedzinie stosunków międzynarodowych, ale w swej książce wykazała się również solidną wiedzą antropologiczną. Jest to $\mathrm{w}$ dużej mierze praca traktująca o podobnych problemach jak omawiana tu książka, zawiera odwołania do tej samej literatury przedmiotu, jednak Kowalski nie odnosi się do niej, nie pokazuje, w czym jego podejście jest inne i czy ewentualnie wnosi coś nowego. Takie ignorowanie pracy kolegów i koleżanek zajmujących się podobnymi tematami jest, niestety, dość częste w polskiej nauce.

Autor zwraca uwagę na fakt, że w omówieniach historii antropologii niewiele pisze się o udziale antropologów w wojnach, i jako przykład podaje kilka pozycji podręcznikowych. Jednak historia antropologii to nie tylko literatura tego typu, o czym autor wie najlepiej, bo powołuje się na wiele bardziej szczegółowych prac historycznych. Mimo to nie odnotowuje pozycji, która w całości jest poświęcona interesującemu go zagadnieniu w odniesieniu do pierwszej wojny światowej ${ }^{11}$. Andre Gingrich w artykule zamieszczonym w tym tomie pisze o wpływie, jaki pierwsza wojna światowa wywarła na antropologię. Podkreśla, że dotyczyło to głównie niemieckiej nauki, a badania nad jeńcami w obozach były początkiem Rassenkunde.

Niektóre obszary (tematyczne i geograficzne) autor pominął w swojej książce. Są one jedynie wzmiankowane. Przede wszystkim dotyczy to antropologii rosyjskiej i radzieckiej oraz historii podboju Syberii i innych regionów, które nie zostały omówione, bo autor uznał, że „informacje o wykorzystaniu wiedzy kulturowej w czasach carskich są stosunkowo dobrze udokumento-

10 Hanna Schreiber, Świadomość międzykulturowa. Od militaryzacji antropologii do antropologizacji wojska, Wydawnictwa Uniwersytetu Warszawskiego, Warszawa 2013.

${ }^{11}$ Doing Anthropology in Wartime and War Zones: World War I and the Cultural Sciences in Europe, Reinhard Johler, Christian Marchetti, Monique Scheer (red.), Transcript Verlag, Bielefeld 2010. 
wane także w literaturze polskiej" (s. 39) i dał odnośniki do prac Antoniego Kuczyńskiego i Wacława Słabczyńskiego, które traktują tylko o udziale Polaków. Należało przynajmniej skrótowo omówić to rosyjskie „wykorzystanie wiedzy kulturowej" lub wyjaśnić, dlaczego się tego nie robi. W odniesieniu do działań Armii Czerwonej i władz radzieckich autor jedynie się domyśla, że takie wykorzystanie miało miejsce, ale pozostanie długo „owiane tajemnicą" (s. 40). Nie wiadomo, czy ta konstatacja jest efektem poszukiwań autora nie zwieńczonych sukcesem, czy jedynie wynika z jego przeczuć. Wydaje się, że nawet w literaturze anglojęzycznej można znaleźć trochę informacji na ten temat ${ }^{12}$.

Autor przyznaje, że marginalnie potraktował również problematykę francuskiego kolonializmu i pominął przedstawienie związków między antropologią a wojskiem w tzw. krajach rozwijających się oraz zaangażowanie antropologów i folklorystów, badaczy etniczności w walkę zbrojną. Daje jedynie odnośniki do kilku publikacji na temat procesów łączących ideologie narodowe i etniczne z aktywnością „liderów kulturowych” i wspomina Radovana Karadžicia i Jomo Kenyattę jako dwa różne przykłady wykorzystania wiedzy antropologicznej w działalności politycznej. Dobrze, że autor przynajmniej zarysował te obszary, których głębiej nie eksplorował, choć zastanawia zupełne pominięcie polskiego kontekstu. Działalność etnografów, którzy ochoczo „polonizowali” „ziemie odzyskane" (mam tu na myśli zwłaszcza prace Bożeny Stelmachowskiej), warta byłaby analizy. Można było pokusić się o sprawdzenie akt IPN pod kątem współpracy badaczy ze Służbą Bezpieczeństwa. Wiem, że takie propozycje otrzymywali już po 1989 roku. Znam także przypadek współpracy polskiego badacza z obcym wywiadem. Jednocześnie warto byłoby podkreślić postawę niezgody niektórych antropologów na działania i politykę państwa wobec mniejszości, czego dobitnym przykładem jest postawa Józefa Obrębskiego w czasie jego badań na Polesiu. Są to kwestie, które ciągle czekają na swych historyków i historyczki.

W książce rzadko omawiane są historyczne reakcje środowiska naukowego na „brudne” działania antropologów, a należało przynajmniej wspomnieć o nich. Na przykład działalność niemieckich uczonych, którzy postulowali rozciągnięcie idei panosmanizmu na tereny Syberii, została gruntownie skrytykowana przez Marię Czaplicką ${ }^{13}$; a Rassenkunde — zdyskredytowana przez brytyjskich antropologów, Juliana Huxleya i A. C. Haddona ${ }^{14}$. Niestety, autor nie od-

12 Np. Marina Mogilner, Homo Imperii: A History of Physical Anthropology in Russia, University of Nebraska Press, Lincoln-London 2013; Francine Hirsch, Empire of Nations: Ethnographic Knowledge and the Making of the Soviet Union Cornell University Press, Ithaca 2005.

${ }^{13}$ Maria Czaplicka, The Turks of Central Asia in History and the Present Day, Clarendon Press, Oxford 1919.

14 Julian Huxley, A. C. Haddon, My Europejczycy. Przegląd zagadnień „rasowych”, Nowa Biblioteka Społeczna, Warszawa 1937. 
wołuje się do fundamentalnego tomu Anthropology and the Colonial Encounter ${ }^{15}$, będącego pierwszą podjętą przez antropologów próbą rozliczenia się z kolonialnym dziedzictwem dyscypliny.

Autor słusznie podkreśla znaczenie antropometrii w służbie niemieckiej idei narodowej i rolę atropologów jako „łowców głów” (podrozdział 1.3.2), ale czytelnik może odnieść wrażenie, że antropometria i badanie czaszek było niemiecką specyfiką. Otóż nie, na przykład antropologia brytyjska też tym się zajmowała. Członkowie ekspedycji Marii Czaplickiej na Syberii w latach 1914-1915 również przeszukiwali groby i gotowali później kości, by je oczyścić z organicznych resztek. Starali się jednak robić to dyskretnie, co nie zmienia faktu, że $\mathrm{z}$ naszego współczesnego punktu widzenia trudno te działania zaakceptować.

Korekty wymaga także kilka pomniejszych spraw. Gertrude Bell w 1914 roku otrzymała złoty medal brytyjskiego Royal Geographic Society (była zresztą jedną z pierwszych kobiet-członkiń tego Towarzystwa), a nie jak podaje autor - National Geographic Society (które było stowarzyszeniem amerykańskim). Autor pisze też: „Ukończyła studia historyczne w Oksfordzie, gdzie jako pierwsza kobieta otrzymała dyplom z wyróżnieniem" (s. 79), co budzi wątpliwości, bo kobiety w owym czasie w ogóle nie mogły dostawać w Anglii tytułów naukowych. Ponadto w zdaniu: „Informacje zebrane w terytoriach północnych Australii” (s. 229), chodziło zapewne o Northern Territory, czyli jedną z prowincji Australii. Autor często opiera się na wynikach analiz czy krytyce innych badaczy, a nie znając wyjściowego materiału czasami niewłaściwie go interpretuje. Na przykład pisze o książce Regny Darnell Invisible Genealogies jako o pracy „poświęconej powojennej spuściźnie naukowej Franza Boasa" (s. 351), a jest to A History of Americanist Anthropology ${ }^{16}$, jak brzmi podtytuł, i autorka, co prawda, podkreśla kontynuację tradycji Boasowskiej, ale się do niej nie ogranicza. Sydel Silverman jest kobietą (wdową po Ericu Wolfie), natomiast autor pisze o niej w formie męskiej (np. „Według Sydela Silvermana”, s. 445). Sol Tax nie był ,jednym z byłych wydawców czasopisma «Current Anthropology»" (s. 454), lecz jego założycielem i długoletnim redaktorem.

W podsumowaniu chcę jeszcze raz podkreślić, że recenzowana praca jest książką bardzo ważną, gdyż analizowany w niej problem wykorzystania w działaniach wojennych wiedzy antropologów o kulturze „innych społeczeństw” oraz towarzysząca temu dyskusja nad etyką badań naukowych są niezwykle istotne dla samoświadomości praktyków i praktyczek dyscypliny oraz ich wrażliwości moralnej i metodologicznej.

\footnotetext{
${ }^{15}$ Anthropology and the Colonial Encounter, Talal Asad (red.), Humanities Press, New York 1973.

16 Regna Darnell, Invisible Genealogies: A History of Americanist Anthropology, University of Nebraska Press, Lincoln 2001.
} 
ANTHROPOLOGISTS ON THE WAR PATH

AND THEIR RELATED MORAL DILEMMAS

\author{
Grażyna Kubica \\ (Jagiellonian University)
}

\title{
Sum mary
}

In the history of anthropology, that is, a science whose borders have considerably shifted, the object of study has continually changed but there has been a prevailing conviction about the unusual sensitivity of its practices; however, such sensitivity has not been discussed by researchers in the context of wars, military intelligence, or other military endeavors. When the history of this discipline is recounted as it is by Michat Kowalski in the book Antropolodzy na wojnie [Anthropologists on War], through the prism of the complications involved in direct activities of this type, it forces one to reflect on the ethical principles that should guide field researchers. Historical analyses of such sensitive material should also incline scholars to greater methodological awareness and avoidance of the trap of presentism.

\section{Key words / słowa kluczowe}

history of anthropology / historia antropologii, methodology of the history of anthropology / metodologia historii antropologii, anthropology and war / antropologia a wojna, anthropology and colonialism / antropologia a kolonializm 